\title{
Business investment: taking stock of the major policy drivers
}

BALÁZS ÉGERT, Ph.D.*

Conference keynote

https://doi.org/10.3326/pse.42.2.2

\footnotetext{
* Received: January 15, 2018

Accepted: January 17, 2018
}

A keynote speech given at the conference "Public Sector Economics 2017 - Public investment: catalyst for sustainable growth" organized by the Institute of Public Finance and Friedrich-Ebert-Stiftung in Zagreb on November 3, 2017. 


\section{INTRODUCTION}

Business investment in many advanced OECD countries has been weak following the 2007/08 financial and economic crisis. This is mostly due to the cyclical effects of weak domestic and foreign demand (the accelerator effect) (Lewis et al., 2014; OECD, 2016). Other factors include funding constraints, increased macroeconomic uncertainty and lower business confidence (Millar and Sutherland, 2016). Other structural factors may have also contributed to this trend of decline. In the longer run, weak investment can have a negative impact on potential growth. Policies should seek to give a boost to investment to prevent permanently lower levels of investment and economic growth. This short note overviews some of the important policy areas capable of helping to underpin business investment.

\section{BETTER ACCESS TO FINANCE IS AN IMPORTANT DRIVER OF INVESTMENT}

It is well understood that good access to finance raises business investment. Financial constraints arise from two sources. First, in countries dominated by bank finance, difficulties in accessing bank loans may penalise small and medium sized firms. This may arise because of weaknesses on the asset side and higher borrowing costs, which can be aggravated by high non-performing loans in the banking sector. Small businesses may face credit rationing as a result of asymmetric information problems, given that they have limited collateral. In part, credit rationing may be explained by lending conditions having been too lenient during the pre-crisis period (Millar and Sutherland, 2016).

Improving the banking sector's efficiency would go a long way to improving access to bank lending. In a number of countries, non-performing loans act as a drag on bank lending. Regulators should help reduce non-performing loans in banks' balance sheets, increase the securitisation of SME debt and introduce credit registry to limit problems related to asymmetric information. Second, deeper equity markets would help channel capital to small and innovative new businesses as they may help bring together high-risk firms with risk-loving investors. For instance, simplifying equity listing would increase the attractiveness of stock markets (Pisu, 2017). Venture capital funding plays a minor role in most OECD countries. One important reason for the domination of bank (and debt) finance over equity finance is the favourable tax treatment of debt. Reducing the tax bias towards debt financing through tighter limits on interest deductibility and tax allowances for corporate equity would help re-establish tax neutrality.

\section{COMPLEX CORPORATE INCOME TAX SYSTEMS COUPLED WITH HIGH RATES MAY PENALISE INVESTMENT}

There is consensus that higher corporate tax rates have a negative impact on business investment via increasing the cost of capital (Sorbe and Johansson, 2016). Large firms benefit more from tax reductions and exemptions whereas small and young firms are less concerned, as they are generally not very profitable (Arnold, Javorick and Mattoo, 2011). For instance, Sorbe and Johansson (2016) show that 
a 5 percentage point increase in the effective marginal corporate tax rate would lower investment on average across industries by about $5 \%$ in the long term. But this effect would be nearly 50\% lower in industries with a high concentration of multinational firms. Profit shifting appears to be partly operating through FDI flows. Such flows alter the cross-border allocation of investment and tax revenues (Skeie, 2016).

Investment in information and communication technology (ICT) and knowledgebased capital (KBC) is an important driver of productivity growth. Many OECD countries lag behind in investment in ICT and KBC. Framework conditions including product and labour market regulations, access to venture capital and bankruptcy laws determine the return on investment in KBC. These framework conditions should not penalise failure (and risk taking) excessively and should allow a rapid reallocation of traditional labour and physical capital to maximise returns on investment in KBC. Public support including R\&D tax incentives and direct support can boost private investment in KBC (Andrews and de Serres, 2012; Andrews and Criscuolo, 2013; Westmore, 2013).

\section{TOO MUCH PRODUCT MARKET REGULATION CAN HARM INVESTMENT}

Less stringent product market regulations are often viewed as boosting investment. If the direct and indirect costs of starting a business are low, the number of business start-ups will increase. This in turn can translate into more investment. Similarly, pro-competitive product market regulation is likely to push firms to invest more to stay ahead of competitors or to allow the entry of new competitors willing to invest. Cutting red tape and administrative burdens reduces the costs related to capital stock adjustment. This could boost investment (Nicoletti and Scarpetta, 2005). More competition (up to a point) gives incentives to invest and innovate to stay ahead of competitors. It pushes for the adoption of better management practices, encourages the investment in organisational, KBC and ICT capital (Fuentes Hutfilter et al., 2016). Therefore, public policies should strive to ease the regulatory burden on starting and running businesses.

Difficulties in restructuring inefficient businesses may keep capital and labour in low-productivity firms and hence penalise investment. Capital trapped in inefficient firms is particularly relevant in Italy, Spain and Finland (Adalet McGowan, Andrews and Millot, 2017). Insolvency regimes are very important for the orderly exit of failing firms. The specific design matters for the efficient functioning of insolvency regimes (Adalet McGowan and Andrews, 2016).

There is a negative link between foreign direct investment (FDI) and regulations aimed at FDI (Nicoletti et al., 2003; Fournier, 2015). Regulations applying to overall/domestic investment have more ambiguous effects. First, entry barriers to specific sectors are likely to discourage greenfield investment but they would encourage foreign investment in already existing firms, which have some market power arising from the existing entry barriers. Second, domestic regulations 
increasing production costs can deter FDI in the export sector, as higher costs would make products less competitive internationally. But stringent regulations can boost the inflow of FDI in the production of goods and services for the domestic market. Less restrictive regulations abroad and the resulting more efficient production structure of firms can give rise to a competitive edge over incumbent domestic firms bogged down by domestic regulation (Nicoletti and Scarpetta, 2005). For instance, reducing cross-country heterogeneity in regulation by $20 \%$ would boost FDI on average by about 15\% (Fournier, 2015).

The impact of labour market regulation on investment is not straightorward. If capital and labour are complementary, more stringent labour market regulations will also have a negative effect on investment and hence capital deepening. But if capital and labour are subsitutes, stricter labour market regulations will boost investment as capital will substitute for labour. The influence of environmental policies on investment is also not very clear. More stringent environmental regulations can trigger investment in more energy-efficient assets. On the other hand, tighter environmental regulations can reduce business investment though raising the costs of capital (Dlugosch and Kozluk, 2017).

Product and labour market regulations need to be coordinated. Even though it is easy to start a business, business dynamics may suffer if labour market regulations are binding (Zwart, 2016). Strict labour market regulations implying costly labour reallocation provides few incentives to invest in and experiment with new technologies (Fuentes-Hutfilter et al., 2016). Also, collective bargaining covering entire sectors can prohibit the entry of new firms as new entrants might pay lower wages than the incumbents (Arnold, 2017).

\section{HIGH REGULATORY UNCERTAINTY IS NOT HELPFUL FOR INVESTMENT}

The higher the uncertainty about the framework conditions, the higher the level of risk, the lower the incentives to invest. Regulatory uncertainty can have damaging effects on investment. Regulatory uncertainty arises if regulations are very complex and difficult to interpret. But regulatory uncertainty also arises if there are frequent and unexpected changes in overall business conditions including administrative procedures involved in starting a business, taxation and product and labour market regulations (OECD, 2016). Designing and sticking to transparent regulations are crucial to boosting business investment. 


\section{REFERENCES}

1. Adalet McGowan, M. and Andrews, D., 2016. Insolvency regimes and productivity growth: A framework for analysis. OECD Economics Department Working Papers, No. 1309. Available at: <https:/www.oecd.org/eco/insolvency-regimes-and-productivity-growth-a-framework-for-analysis.pdf $>$

2. Adalet McGowan, M., Andrews, D. and Millot, V., 2017. The walking dead? Zombie firms and productivity performance in OECD countries. OECD Economics Department Working Papers, No. 1372. Available at: $<$ https://www. oecd.org/eco/The-Walking-Dead-Zombie-Firms-and-Productivity-Performance-in-OECD-Countries.pdf $>$

3. Andrews, D. and Criscuolo, C., 2013. Knowledge-based capital, innovation and resource allocation. OECD Economics Department Working Papers, No. 1046. Available at: $<$ http://www.oecd.org/officialdocuments/publicdisplaydo cumentpdf/?cote $=\mathrm{ECO} / \mathrm{WKP}(2013) 38 \&$ docLanguage $=\mathrm{En}>$

4. Andrews, D. and de Serres, A., 2012. Intangible assets, resource allocation and growth: A framework for analysis. OECD Economics Department Working Papers No. 989. http://dx.doi.org/10.1787/5k92s63w14wb-en

5. Arnold, J. M., Javorcik, B. S. and Mattoo, A., 2011. Does services liberalisation benefit manufacturing firms? Journal of International Economics, 85(1), pp. 136-146. https://doi.org/10.1016/j.jinteco.2011.05.002

6. Arnold, J., 2017. Raising business investment in Portugal. Paris: OECD mimeo.

7. Dlugosch, D. and Kozluk, T., 2017. Energy prices, environmental policies and investment: Evidence from listed firms. OECD Economics Department Working Paper, No. 1378. https://doi.org/10.1787/ef6c01c6-en

8. Fournier, J., 2015. The negative effect of regulatory divergence on foreign direct investment. OECD Economics Department Working Papers, No. 1268. Available at: <http://www.oecd.org/officialdocuments/publicdisplaydocumen tpdf $/$ cote $=\mathrm{ECO} / \mathrm{WKP}(2015) 86 \&$ docLanguage $=\mathrm{En}>$

9. Fuentes Hutfilter, A. [et al.], 2016. Boosting investment performance in Germany. OECD Economics Department Working Paper, No. 1326. Available at: $<$ http://www.oecd.org/officialdocuments/publicdisplaydocumentpdf/?cote $=\mathrm{E}$ $\mathrm{CO} / \mathrm{WKP}(2016) 50 \&$ docLanguage $=\mathrm{En}>$

10. Lewis, C. [et al], 2014. Investment gaps after the crisis. OECD Economics Department Working Paper, No. 1168. http://dx.doi.org/10.1787/18151973

11. Millar, J. and Sutherland, Dd., 2016. Unleashing private sector productivity in the United States. OECD Economics Department Working Paper, No. 1328.

12. Nicoletti, G. [et al.], 2003. Policies and international integration: influences on trade and foreign direct investment. OECD Economics Department Working Papers, No. 359. https://doi.org/10.1787/062321126487

13. Nicoletti, G. and Scarpetta, S., 2005. Regulation and economic performance: product market reforms and productivity in the OECD. OECD Economics Department Working Paper, No. 460. https://doi.org/10.1787/726517007575

14. OECD, 2016. OECD Economic Survey of Hungary. Paris: OECD. 
15. Pisu, M., 2017. Promoting a private investment renaissance in Italy. $O E C D$ Economics Department Working Paper, No. 1388. Available at: $<$ http://www. oecd.org/officialdocuments/publicdisplaydocumentpdf/?cote=ECO/WKP (2017)20\&docLanguage $=\mathrm{En}>$

16. Skeie, O. B., 2016. International differences in corporate taxation, foreign direct investment and tax revenue. OECD Economics Department Working Paper, No. 1359. Available at: <https://www.oecd.org/eco/International-differences-in-corporate-taxation-foreign-direct-investment-and-tax-revenues.pdf $>$

17. Sorbe, S. and Johansson, A., 2016. International tax planning and fixed investment. OECD Economics Department Working Paper, No. 1361. Available at: $<$ https://www.oecd.org/eco/International-tax-planning-and-fixed-investment. pdf $>$

18. Westmore, B., 2013. R\&D, patenting and growth: The role of public policy. OECD Economics Department Working Paper, No. 1047. https://doi.org/ $10.1787 / 5 \mathrm{k} 46 \mathrm{~h} 2 \mathrm{rfb} 4 \mathrm{f3}-\mathrm{en}$

19. Zwart, S., 2016. Enhancing private investment in the Netherlands. $O E C D$ Economics Department Working Paper, No. 1305. Available at: <http://www. oecd.org/officialdocuments/publicdisplaydocumentpdf/?cote=ECO/WKP (2016)29\&docLanguage $=\mathrm{En}>$ 